\title{
The Mental Element of The Crime of Fault in The Performance of The Official Jobs: Article (341) of The Iraqi Law
}

\section{Wajdi Sabah Mahmood ${ }^{1 *}$, Mahdi Khaghani Esfahani ${ }^{2}$, Majid Ghurchibeygei ${ }^{3}$}

${ }^{1}$ Researcher, PhD in Criminal Law and Criminology at Kharazmi University, Tehran, Iran.

${ }^{2}$ Assistant Professor of Criminal Law \& Criminology, the Institute for Research and Development in the Humanities (SAMT), Tehran, Iran.

${ }^{3}$ Assistant Professor of Criminal Law \& Criminology, Kharazmi University, Tehran, Iran

*wjdeeesbah@gmail.com

\section{ABSTRACT}

Faulty execution of official duties is regarded as one of the main offences that endangers elected authorities, a well-ordered public regulation, and utility that causes harm to public property and public interests. Since it is done by an individual who is performing an official work, this offence is committed by one of the workers violating the boundaries of their employment. This is enshrined in Iraqi penalty Law No. 111 of 1969 in article 341 and is deemed one of the financial and administrative corruption offences stipulated in the honesty Commission Act No. 30 of 2011 due to its extreme and significant danger and leaving traces and impacts. The consequences of this major crime and its effect on the state and community is expressed in the legal, democratic, administrative, fiscal, and social structures of the state. It is described as accidental offenses committed without criminal purpose. In this form of crime, neither initiating nor participating is possible, but both of the perpetrators are simple owners. In certain ways, this offence is analogous to the crime of willful injury to public property and interests, in addition to all other general criteria for any crime.

Keywords

Fabuse of power, Iraqi administrative law, Crimes of offials, Not-deterrent law Article Received: 10 April 2021, Revised: 10 April 2021, Accepted: 11 April 2021

\section{Introduction}

Any time and location, the law strives to accomplish a lofty ideal symbolized by the concept of justice, and the spiritual component is no less essential than the substantive one (Faults) The Faults is the second picture of the moral aspect of unintended offences, and as such it is a description that deviates from the will, rendering it susceptible to manipulation (blaming the law) If crimes are to be deliberate and their moral component is criminal intent, so certain crimes can be accidental, and unintended crimes have gained particular attention in contemporary culture as a result of the introduction of many methods that demand diligent application and consequently result in unintentional crimes. This is since unintentional crimes are more prevalent than intentional crimes, and therefore the legislator must intervene explicitly to define unintentional crimes and, in our case, to define the crime in question in Article (341) as one of the financial and administrative corruption crimes committed 
by a public servant or person charged with a public service.

The first subject of this research will cover the meaning, picture, and types of faults, while the second topic will be divided into two criteria. We would discuss the first criterion, the definition under which the Fault is calculated, the elements that must be included in the Fault, as well as the magnitude of the Fault needed to establish the employee's liability for this crime, and the second requirement, the relationship of the Fault. With regard to some legal phenomena, which we will address in detail.

\section{Chapter 1:}

Fault, its graphic, and its forms are

linguistic and idiomatic concepts.

The first prerequisite / Fault's linguistic and idiomatic definition

The first branch is focused on the linguistic principle of Fault.

The flaws are as follows: moving away from the facts, And then there are the branches: One of them is: you want anything else than good will, so you do it, and this is the whole fault for which an individual is recognised.

The Almighty said (Truly, their murdering is indeed a tremendous sin.1), and we have surely been guilty of $\sin ! 2$

The second is that he tries to do what he does best, but there is a paradox, because he is told: He made a Faults, he is incorrect, and this has wronged his will and created a Faults.

This is the essence of his saying, peace be upon him: (Flaws and forgetfulness have been taken from my nation).

Second, this is the idiomatic definition of Fault.

The Fault in general is the divergence from the expected behaviour, which involves the total deviation in this context. However, whether meant or not, the Fault in the criminal convention has a unique concept.

The texts of the law are usually performed on the use of (Fault) synonymous with (intentional), and among jurists, whoever makes careful use of the word Fault and does not release it abstractly, pushing for confusion and a precaution against confusing it with deliberate Fault, however the conventional concept of the erroneous term has settled in the language of the legislation to the contrary.

A declaration of the representations of the Fault should not replace a statement of what it is, since the picture is just a form and not an essence, and the Fault is a concept in and of itself, as the Iraqi legislator followed. If the criminal outcome happened attributable tothe perpetrator's error, whether it was incompetence, recklessness, lack of care, lack of precaution, or non-observance of rules, legislation, and orders), the offence is not deliberate.

The above text implies that the unintended offense is the crime caused by the Faults, given that the Faults take one of the forms listed by the legislator in the article's text.

Based on this, we would discuss certain concepts of Fault based on the views of some criminal law experts, where Fault was described (as the course of a person's will to engage in risky conduct without taking the requisite precautions).

He explains the Fault (it is every act or willful omission that results in results that were not intended by the perpetrator, but he could and should avoid them). He determines the Fault (it is any behavior or willful inaction that results in outcomes that the offender did not expect, nor that he might and could avoid). 
We will see that the Fault may be established (which is the course of the actor's will to the conduct - whether an act or abstinence - that culminated in a negative outcome that he did not plan, and the offender did not foresee, and he was obliged to anticipate it or anticipate it, and only he can prevent it).

\section{Second: The Fault Mages and Their Varieties}

In the first part of this requirement, we will discuss the styles of Fault that have been introduced into Iraqi law, and in the second section, we will discuss the kinds of Fault that have been introduced into Iraqi law.

The first section is for different types of fault.

The text of Iraqi Law No. 111 of 1969, as revised in Article 35 (a offence is accidental whether the criminal outcome happens as a consequence of the perpetrator's Faults, if these Faults be incompetence, recklessness, lack of consideration, lack of care, or failure to observe rules, regulations, and orders).

\section{First - Ignorance}

It is a flaw that happens in a pessimistic mindset by leaving, abstaining from, or failing to take steps that are required by vigilance to deter the adverse result from happening. For example, the plant or warehouse owner's failure to take the requisite fire safety precautions.

\section{Second, there is frivolity.}

A word that refers to recklessness and lightness, and it is an inaccurate translation of its French origin (Maladresse), which means poor judgment, lack of skill, or ignorance of technical matters that should have been known, such as a doctor who performs a transplant without first examining the patient's blood type or a doctor who performs A suture without first examining the patient's blood type.

Third, there is a lack of focus:

It comprises of an unexplained recklessness or lightness, which means failing to do what can be accomplished to prevent adverse repercussions, and is similar to neglect as negative conduct that results in a criminal outcome, and negligence and lack of action was accomplished through the employee's failure to take the required precautions to avoid the incidence of the unlawful effect. Fault is accomplished by abstinence and abandonment. And it differs from the image of a lack of precaution in that the latter assumes that the employee adopts a positive attitude without taking precautions to ensure that the harmful effects of the act are avoided, such as guarding the railway passage if he does not initiate warning passers-by in a timely manner and alert them to the nearness of the train and is lax in closing the passage from Its backgr

Fourth, there is a lack of precaution and caution.

It is a depiction of the Fault engaged in a positive activity that is characterized by a lack of insight into the consequences, because the lack of precaution and precaution is achieved if the perpetrator does his act knowing that his risk could have harmful effects on him, but he may not take precautions to ensure the risks are avoided, and the majority of applications of this image are of car accidents. 
Fifth, noncompliance with rules, legislation, and instructions

This image indicates that the perpetrator's behavior was not in accordance with the rules established by laws, regulations, and regulations, which resulted in the crime's outcome, and the expression (laws, regulations, and orders) expanded to all the peremptory rules of behavior issued by the state, regardless of the authority that specialized in issuing them, especially the rules that prevent the consequences of the crime. The unlawful offences committed by (unintentional crimes) such as traffic and transit laws, as well as regulations for public health and numerous occupations and sectors. It also applies to certain Penal Code laws and disciplinary directives, but simply failing to follow the laws and guidelines is not enough to establish blame for an accidental offence. Rather, all of the Fault factors must be met, and there must be a direct relation between the conduct and the criminal consequence.

Ray claims that only the Fault's pictures were stated and that a Fault cannot be punished until it takes a copy of the Fault as specified in the Penal Code.

Others, though, contend that the first view is flawed since the legal texts do not justify it. Some mention just one or two pictures of the Fault, whereas others name more. Nonetheless, it is not acceptable to claim that the extent of the Fault varies strictly and generally depending on the number of images specified by statute. Because of the essence of unintended offences, the extent of Fault converges in both of them, which suggests that the images described were, for example,

Another school of thought holds that the provisions of the statute is broad and vague enough to include all types of fault.
The second branch: types of Fault The unintended Faults are classified under criminal law into the following categories, in the following order:

First, a major flaw and a minor flaw According to Roman rule, some go to split the Fault according to the degree of seriousness of its severity to the severe Fault, and it is available until all should anticipate the wrong outcome. A basic Fault is reached where the expected outcome is not obtained. It is discovered in the outcome's anticipation that it is only probable for an exceptional individual who outperforms the normal person in terms of the degree of his vigilance, treatment, and consideration.

Those who argue that this difference is essential in penal law claim that the law only acknowledges gross fault, and that simple faults result in civil liability. This argument, however, has been proved to be false, as the theory of (the unity of criminal Fault and civil Fault prevailed) The most serious flaw of this distinction is that it lacks a norm on which to base itself; indeed, its very nature undermines it. The Fault in the penal law has one criteria, which is the norm of (the ordinary person), which necessitates the use of another criterion as a criterion (the very cautious person) and the establishment of a differentiation between severe Fault and basic Fault dependent on it. A argument that contradicts the fundamental concept of Fault.

In Iraqi rule, the legislator stipulated that a grave Faults is called an image of the moral aspect and employee Fault's offense. The jurisdiction by which he serves. .......... etc.) and, as a result, whether the Faults are not significant, the employee's error may not be realized. In Article, the Iraqi has stipulated a significant Fault for the employee for the offence to be realized (341). 
Second, there is a technical fault and a material fault.

Professional Fault refers to errors committed by artists such as surgeons, pharmacists, architects, and attorneys in the performance of their careers, and this Fault is defined by comparison to science and technical laws that specify the exact roots of these professions. It is one of my favorite things about it.

The substance Fault is a violation of the duty enforced on all individuals by the laws of universal human experience of the need to take the required precautions while doing a certain action to prevent the adverse effects that it may result in. The owner of the practice while conducting his profession without this Fault having little to do with the technical roots of this profession.

As a result, the content Fault is attributed to a lack of the general prudence and warning duties that all individuals, even artists in the scope of their careers, must follow, as they must follow certain general duties until they follow science or technological guidelines. Supporters of this distinction claim that whether the fault is egregious, creative or intellectual failure does not justify criminal prosecution.

To summarize, the differentiation between physical and mechanical fault has become redundant owing to the unity of the nature of fault in any picture and the absence of any justification for this distinction in terms of fact or statute.

Third, there is criminal and civil liability.

The implications of committing the Fault determine whether the Fault is illegal or legal. Judicial Fault occurs where an infringement of a lawful regulation results in an injunction or final combined with a punitive sentence, while civil Fault occurs where a person breaches the duties that he has agreed to or imposed on him by the rule of law or the essence of the matter being treated, or when the conduct carried out by this failure causes injury to someone without being criminalized.

Damage is an important factor of establishing civil responsibility and the factors that comprise criminal Fault, with the exception that criminal Fault includes prosecution if the incorrect conduct is technically criminal and punishable, while civil Fault entails just restitution in the absence of a criminal text that converts it into criminal Fault.

The independence of the criminal Fault from the civil Fault in its content, concept, and objectives allows the criminal judge to assess the availability of the Faults and decide on the punishment, while the principle of unity of the two Faults prevents the judge from pronouncing the correct judgment, whether innocent or guilty, and so the owners of this opinion see (double Fault).

While other views went to the saying (by unity of Fault) in the sense and degree of the two codes, which implies that a minor Fault is rendered by criminal negligence, much like civil responsibility is made by criminal responsibility. Supporters of these points of view denied that the social role of civil liability differed from the social function of criminal responsibility. According to Article (227 / a) of the Criminal Procedures Law, the Iraqi legislator has authorised Fault's unit in the criminal and civil fields.

part two:

The moral element of the crime of an employee's Faults in performing the public office:

The legislature demands the presence of a serious Fault for the moral aspect to be established for the crime of Fault in the 
performance of public office, so we split this analysis into two conditions. In the first requirement, we deal with the criterion under which the Fault is calculated, as well as the elements required in the Fault and the seriousness of the Fault in order to obtain the employee's liability for this offence, and we investigate another group the Fault's relationship. With certain ethical phenomenon, which we can go through in detail.

\section{The first criterion is as follows:}

\section{Elements of Fault and magnitude of} gravity needed for the public servant's issue:

As the Faults is a person's violation of the duties of care and caution enforced by the statute as he acts, if this is seen as a representation of job incompetence or a breach of job duty and misuse of power, and not stopping him appropriately without his actions contributing to a criminal result, we will split this provision into two parts that we cover in this segment. The first branch is the Fault criterion, and the second branch is the components of unintended Fault.

\section{The First Section :}

\section{Criteria for Inadvertent Fault}

First, consider the personal principle (or personal criterion):

It is a measurement of the perpetrator's actions under specific situations based on his normal behavior. If his conduct is less careful and cautious than he is used to under certain situations, a violation of his duties is attributed to him; but, if his behavior fits the cautious fact to which he is accustomed, the breach is not attributed to him.

Due diligence, according to this criterion, is measured by the treatment that the suspect is used to under such situations as the crime, which implies that we depend on the accused's actions and previous roles as a criterion for evaluating his behavior.

The strictly personal criteria is the criterion that is applied to the suspect himself in its assessment based on his personal makeupand unique conditions such as his level of intellect, qualifications, and personal experience.

\section{Second, this is objective philosophy (objective criterion)}

This hypothesis is founded on the fact that due and probable precaution is defined by the norm of the ordinary, prudent man who performs his actions with care, the diligent head of the household, and that preventing the unlawful outcome is a responsibility in the abstract, that is, according to the public perception existing at the time and place of the offence.

As a result, the perpetrator's (the employee's) conduct is determined by the behavior of a particular individual, and the officer is the normal person or a person of average diligence, care, and caution. According tothis cop, the employee's violation of the duties of vigilance and caution is subject to his standing back from what the abstract individual is bound by, regardless of what (the employee) is normally dedicated to in his conduct. 
As a result, the objective officer is the correct and precise criterion in which the issue of the employee or person charged in a public service is based in the event of committing the crime of Fault in performing the public office, however it is not taken absolutely or abstractly from the external circumstances that surrounded the employee at the time of the crime, such as

Thus, it may be concluded that the ordinary person was surrounded by the same circumstances as the perpetrator when the crime occurred, and we must therefore determine if the perpetrator and his circumstances adhered to the requisite degree of caution and caution that the ordinary person was subjected to in these circumstances. Whether he was committed, he did not assign the act to him, and the explanation for that is (no commitment is impossible), because there is no place for you to expect others to stick to the person's normal conduct because the conditions around their behavior make it under their control. And that the Iraqi judiciary has adopted the objective norm.

\section{The second section discusses the aspects of unintended fault.}

The Fault is founded on two elements: the violation of the duties of prudence and vigilance enforced by the constitution, and the existence of a psychological bond that links the perpetrator's will and the criminal consequence that happened, which we will address in this section as follows:

First, this is a violation of the obligations of prudence and vigilance.
It is important for us to decide the source of the duties of prudence and caution and how to break them, and determining the source of the duties of prudence and caution is not difficult since the laws of law are the first source that enforce these duties if their obedience to them is not in question. When the statutes, directives, regulations, and regulatory guidelines are determined in all their ways - all the established legal origins are the same - the actions issued by the state, whatever the authority it decided, will extend - along with the legal laws in their ordinary sense - but the statute is not the only source of the duties of vigilance and caution. In and by itself, because of the societal advantages it can gain, such as conducting surgeries and driving vehicles, and considering his approval for them, taking them may constitute a violation of prudential duty.

Either the second source of prudence and caution is (human experience), whether general or technical, that must be considered. Thus, the general basis of the duties of caution and caution is general human experience, since this experience determines a series of guidelines specifying the proper response to a certain form of action. Science, the arts, and practical concerns also add to this expertise.

Second, there is a psychological connection between the will and the criminal consequence.

The Faults were not founded solely on a violation of the duties of vigilance and caution, since the statute is not punitive for actions in and of itself, but rather for action that contributes to a particular criminal effect. And there must be a relation between the will 
and the outcome in such a way that the will for this result is subject to the law's fault, so it is justified. As a result, whether it is spoken to as a suspect would. Without this interaction, the individual cannot inquire about the event of the outcome, and for this reason, the psychological relationship between the will and the result has two kinds, namely:

\section{A: Visualization of the crime outcome's unpredictability (unconscious Fault)}

It is possible to establish that the Fault is beyond expectation necessitates the fulfillment of three criteria, namely: -

1- The outcome is expected: that is, the result is probable due to the existence of the Fault that happened, since its incidence remains a reasonable and familiar thing, rather than an exception or odd one.

2- Because the suspect would not expect this outcome: in this case, the perpetrator's will may be confined to committing or not performing the wrong act solely regardless of his mistaken belief or wrongful conduct within the circumstances of the event in which he was discovered.

3- Because it is the perpetrator's responsibility or his capacity to predict the outcome.

\section{B: Visualize forecasting the result (conscious Fault)}

This condition occurs where the perpetrator's (the employee's) will is guided towards the criminal action while anticipating the criminal consequence to emerge as a potential product of his behavior without his will being oriented towards or accepting this result. The Fault can be seen in two ways: The first example involves the anticipation of a criminal outcome and the inability to take sufficient measures in the absence of its existence, including the fact that the perpetrator may have taken adequate precautions. The second scenario involves anticipating the criminal result and the perpetrator's aversion to it, i.e. failing to take action to deter it from occurring.

The root of the deliberate Fault is the perpetrator's understanding of the probability of the criminal consequence arising from his conduct, however his failure to take the requisite steps to deter it from occurring, which was his responsibility and which he was willing to take. Objective and personal, this Fault would be known until it is shown that the regular, logical, and rational individual, if he had the belief that circulated in the accused's mind, would not have continued his conduct in the manner that the latter did. 12

\section{The second prerequisite}

Employee violence and its connection Faulty performance in public office is one of many legal phenomenon.

There are several legal issues that have caused controversy among jurists about accidental crimes in general, the connection of these crimes to some legal phenomenon, and whether there is a distinction between deliberate crimes and unintentional crimes in terms of the effect of these phenomena on them, so we divided this segment into the following: 


\section{The first section considers the degree of which the attempted crime of Fault in the performance of a public office can be realized.}

Ray considers the risk of conceiving the commission of wrongdoing. The rationale for this viewpoint is that, looking at the material act itself and the findings that can be obtained, it can be stated with him that the initiation of Fault offenses is possible, where the negligent act itself is taken into consideration in material terms to validate the outcomes that can be obtained. The behavior is defined as an effort in the crime if the conduct of the crime is halted or the outcome that is deemed a normal consequence of the act performed by the criminal for purposes outside of his will, and this opinion ends by stating that the penalty is for the implementation of the crime. Crimes of Fault are a matter expected by justice, but thisview, although acceptable in principle, meets an impossibility in practice, since in the crimes of Fault where the perpetrator's purpose would not go to do a real offense, if the negative outcome is not accomplished, it is impossible to conclude this on the one side and from the evidence on the other. However, the situation gets more complex as we realize that the majority of Fault offenses exist adversely and that their only constructive manifestation is the damage caused by them, as well as that penalty for attemptingincorrect crimes is seen as a danger that actively undermines people's freedoms. For the purpose of criminal prosecution.

While another school of thought holds that the absence of initiation in wrongful crimes is due to the availability of the will to complete the crime in all of its elements, not only the will to act or leave, and because the intent is negated in unintentional crimes, even though they are complete, it is a matter of the first to be excluded in the initiation of Fault if it was serious and issuable. However, it cannot be called an effort to do such significant damage, since the faults that cannot be identified as an attempt in an unintended offense can be considered an individual crime, deliberate or unintentional, such as pursuing a medical career without a certificate or violating traffic laws and guidelines.

The Iraqi law states in Article (30) that the initiation (is the initiation of the execution of an act with the intent to commit a felony or misdemeanor whether it ceases or fails in its effect for reasons unrelated to the will of the perpetrator) and from this text it is clear that the criminal intent is the whims of the pillars of the initiation and because the criminal intent

The second branch: the degree to which it is possible to participate in the offense of Fault in the performance of public office.

My criminal jurisprudence opinion goes to the likelihood of conceiving complicity in Fault's offences, and the reason for this opinion is that the law's rules pertaining to ancillary contribution have been formulated to cover all offenses, whether willful or accidental. That the partner's person has the moral elements that are required for the occurrence of the crime, then if the material elements of the ancillary contribution are present next to it, so there is little evidence to justify his lack of responsibility for it, and the moral elements of the crime are available if there is a Faults, so saying that the criminal intent is one of the elements of this a crime. And their answer to this is that the statute needs knowledge of computers, arms, and means that the shareholder provides to the perpetrator, and that finding knowledge does not imply requiring unlawful purpose, since 
the latter does not carry out knowledge alone, but rather the will on his hand.

It is sufficient for the availability of the moral aspect to partake in unintended crimes that the participant knows of the perpetrator's initial conduct, which is marked by incompetence or lack of caution, and that the desire of the contributor to this act is accessible for him without proceeding to the circumstances of the outcome that occurred. The same adverse consequences when complicity in intentional crimes is not needed - clearly - and in the crime of Fault in doing the work, it is appropriate for the spouse to recognize the perpetrator's acts and predict the resulting outcome from them. However, he does not take any measures or exercise any diligence to avoid this outcome. Or, if his will had lost because it did not assume what he should have intended so it could not use her perceptual property correctly, it did not anticipate this negative result, even though it should have.

Another school of thought holds that involvement in any felony necessitates the desire to aid the initial victim in completing the crime. Assume that this purpose was not present in the initial perpetrator's act in the unintended offense. In any situation, it is not a question of importance in the act of the associate from which he borrows his criminal character and therefore the contribution of some criminal organization. A wrongful act or omission can make its owner a legitimate offender whether it ends in a legally punishable outcome, except if the wrongful act or omission seems to be incitement, agreement, or help in a Faults created by another party, and so both the spouse and the original victim are called original actors. There is no distinction of Faults or their degrees in the case of accidental violence.
In reality, the crimes of Fault are of a unique kind, and no one can affirm the legitimacy of their involvement. Assume that the presence of the perpetrator's unlawful motive is required for an intended crime. In any scenario, the offences of Fault necessitate the existence of the Fault when the prosecution of them is over the Fault that happened by the victim rather than the course of the motive of an illegal act. And that someone who leads to the event of damage is deemed a participant in the offence, whether a material or moral actor. In deciding the legal adaptation of those that lead to these offences, the owners of this opinion varied. Ray went on to say that the Fault contributor, if he plays a minor part, is not called into doubt. While a second view saw everybody who contributed to the Fault as an actor in their own crime, a third saw the suspects as initial contributors to one unintended crime. Participation of unintended crimes cannot be realized in the place of the Iraqi legislator.

\section{Conclusion}

We came to the following conclusions and suggestions as a result of our research:

We inferred that the Iraqi legislator did not have a clear concept of Fault in performing a public service in the Penal Code provisions since it is the spiritual aspect of the crime of Fault in performing a public office, which is one of the unintended crimes.

We discovered through research that there is no need to list the photos of unintended Fault since they are interconnected synonyms and are not comprehensive, but rather an illustration.

We came to the conclusion that the Iraqi legislature accepted Fault's solidarity in the criminal and civil worlds. 
We argued that the legislator used an objective criterion (objective theory) to compare the perpetrator's (the employee's) conduct to that of a particular individual and the ordinary, and the officer is the normal person or the person of average consideration and caution.

We concluded that the crime of an employee's Faults in the Performance of a Public Position is realized in light of the Iraqi Penal Code, specifically Article (341). The fault must be severe and cause significant harm.

We concluded that acknowledging the intended outcome is what separates probabilistic motive from conscious or expected fault, as seen in contemporary criminal law.

We came to the conclusion that an attempted offense of Fault in the performance of public office is unthinkable.

We also concluded that involvement as a co-contributor to Fault's wrongdoing in the performance of public office is not permissible. Rather, since they are the initial suspects of the offense, each contributor is questioned.

Alhamdulillah

\section{References}

First: - The Holy Quran

Second: - Legal books: -

1- Al-Allama Al-Ragheb AlIsfahani, Vocabulary of the Phrase of the Qur'an, Dar AlQalam, Damascus, Fourth Edition, $1425 \mathrm{AH}$.
2- Awad Mohamed, Penal Code, General Section, 1998, University Press, Alexandria.

3- Abd Al-Muhaimin Bakr, Special Section in the Penal Code, Crimes of Assault on Persons and Money, 1968, Dar Al-Nahda Al-Arabiya, Cairo.

4- Samir Alia, Explanation of the Penal Code, General Section, without a place of printing, without a year of printing.

5- Abdul Rahman Tawfiq Ahmed, Lectures on the General Provisions of the Penal Code, Part One, First Edition, Amman, Wael Publishing House, 2006.

6- Muhammad Subhi Negm, Penal Code - General Section, General Theory of Crime, year 2000.

7- Fawzia Abdel Sattar, The General Theory of Unintentional Fault, Dar Al-Nahda Al-Arabiya, 1977.

8- Mustafa Al-Ouji / General Criminal Law, Part Two, Criminal Responsibility, Second Edition, Beirut, in 1992.

9- Kamal Al-Saeed, Explanation of General Provisions in the Penal Code, without place of publication, 2002.

10-Mamoun Muhammad Salama, Penal Code (General Section), Third Edition, Arab Thought House, Cairo, 1990.

11-Mustafa Muhammad Abdel Mohsen, The Unintentional Fault of Criminal Responsibility and Cassation Control. 
12- Ali Hussain Khalaf, Sultan Abdul Qadir al-Shawi, General Principles in the Penal Code, Sanhouri Library, new edition,.

13-Mahmoud Naguib Hosni, Explanation of the Lebanese Penal Code - General Section, Arab Renaissance House, Beirut Lebanon..

14- Abd Al-Muhaimin Bakr, Special Section in the Penal Code, Crimes of Assaults on Persons and Money, Dar Al-Nahda AlArabiya, Cairo, 1968.

15-Raouf Obaid, Crimes of Assaults on Persons and Money, Sixth Edition, Dar Al Fikr Al Arabi, 1974.

16- Abu Al-Yazid Ali Al-Matit, Crimes of Negligence, Alexandria Culture Publishing House.

17-Al-Saeed Mustafa Al-Saeed, General Provisions in the Penal Code, Fourth Edition, Dar Al Maarif, Egypt, 1962.

18- Wadad Abdul Rahman Al-Qaisi, The Crime of Negligence, a Comparative Study, Law and Judiciary Library, 2015.

Third: - Research and dissertations: -

1- Ihab Yuser Anwar Ali, Unintentional Fault in penal and civil law, thesis for a master's degree in law, 1991.

2- Maher Abd Shwish, The General Theory of Unintentional Fault in
Criminal Law, University of Baghdad PhD Thesis, 1981.

3- Youssef Elias Hassou, Criminal Responsibility for Unintentional Fault, Master Thesis, Baghdad, 1971.

Fourth: - Articles and

Research Journals: -

1- Adel Yousef Al-Shukry and Maytham Hussein AlShafei, Recent Trends in Defining Unintentional Fault, Al-Kufa Magazine, Issue Two.

2- Mahmoud Naguib Hosni, Unintentional Fault , research published in the Lawyers' Journal, fortyfourth year, March 1964, Issue 7-6. 